\title{
A semantic comparison of the conclusion of LXX Tobit and Semitic 4QTobit
}

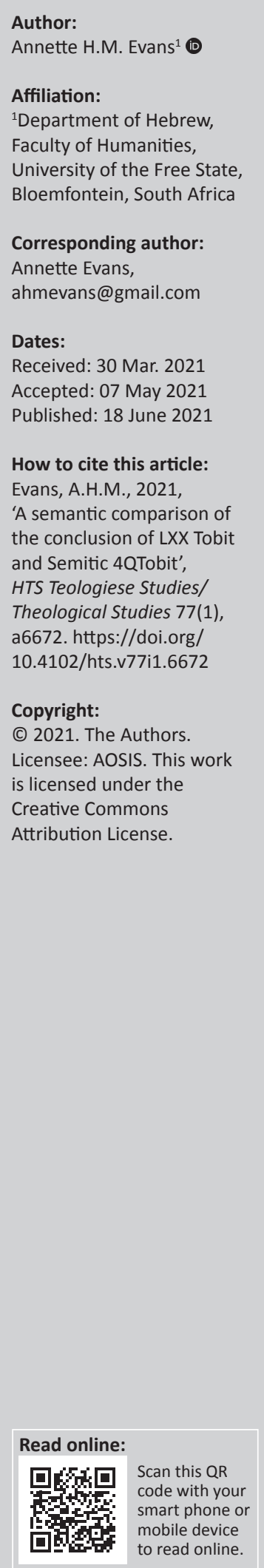

At the beginning of the 20th century, the shorter Greek version of the book of Tobit, GI, which is included in the Catholic Bible, was thought to be the oldest version. It was defined as 'a lesson on almsgiving and its redeeming powers'. As the discoveries of the Semitic copies of Tobit at Qumran, GI is recognised to be a reworking of the longer version GII, most probably originally written in Aramaic, between 225 and 175 BCE. In all versions of Tobit, the theme of almsgiving is introduced as specifically directed to Jewish kinsmen, but towards the end, is to be directed to all poor, suggesting that it may have been written by a Hellenistic Jew. Although the surface context of the narrative of Tobit is the Jewish tradition of proper observation of mitzvot and sacrifice and eventual reward, the various versions contain varying degrees of ancient Near Eastern wisdom, and an ironic, subversive reflection of hypocritical righteousness. This article questioned why the endings differ markedly in different versions. To try to find answers, a semantic comparison was made between GI and the most complete Aramaic version 4Q196.

Contribution: This article considered the implications of source criticism in the reception of the various versions of Tobit. The possibility was examined that the pre-Christian, Aramaic version 4Q196Tobit does not confirm the excessive focus on almsgiving as righteousness apparent in the GI version of LXX Tobit.

Keywords: LXXTobit; Semitic4QTobit; 4Q196Tobit; 4Q200Tobit; almsgiving; righteousness; mercy; wisdom literature; Deuteronomy.

\section{Introduction}

It is not known how old the earliest Greek version of Tobit is. The shorter GI version was preserved by the church, contained in Codex Sinaiticus. The one Hebrew 4Q200 and four Aramaic versions 4Q196-199 found at Qumran are the oldest extant pre-Christian versions we have. Although the surface context of the narrative of Tobit is the Jewish tradition of proper observation of mitzvot and sacrifice and eventual reward, the various versions contain varying degrees of ancient Near Eastern wisdom, and an ironic, subversive reflection of hypocritical righteousness. ${ }^{1}$ Could a better understanding of the differences in the rhetorical currents in the earliest versions cast light on the cross currents in the Jewish roots of early Christianity? The discoveries of the Semitic copies of Tobit at Qumran suggest that Tobit was most probably originally written in Aramaic, between 225 and $175 \mathrm{BCE}$, and that GI is a reworking of GII. ${ }^{2}$ At the beginning of the 20th century, the shorter Greek version GI was still regarded as the oldest version of Tobit. The book was depicted as 'a lesson on almsgiving and its redeeming powers', but GI emphasises the rewards of almsgiving to such an extent that today a 'prosperity cult' comes to mind (Kohler 1906:1).

The trigger for this study was that in the transcription, reconstruction and translation of the Semitic fragments of Tobit in DJD, the lexeme צדק [righteousness] is translated as 'almsgiving'. Yet, the Greek translators of Tobit found something in the versions they translated from, presumably Semitic, which they rendered as $\dot{\varepsilon} \lambda \varepsilon \eta$ [mercy], not righteousness. It was the lexeme $\dot{\varepsilon} \lambda \varepsilon \eta$ 'mercy' in the Septuagint, not $\delta i ́ \kappa \eta$, which was subsequently rendered into English as almsgiving. The rationale for Fitzmyer's rendering of the lexeme צ' צ' almsgiving is that at some point, during the Second Temple period, צדק became a synecdoche for almsgiving because almsgiving was believed to result in a state of righteousness 1.For a discussion of rhetoric in Tobit, see Amit 2000.

2.The most complete earliest Greek version of Tobit was found in Codex Sinaiticus (Fitzmyer 2000:47). Stuckenbruck and Weeks (2015:238) state that the Old Latin may contain older material in parts, where it differs from Sinaiticus, but it presents many problems. Simkovich (2019:1) estimates that Aramaic Tobit was probably written in Judea between 225 and 175 BCE, but Dimant (2009:347) favours an earlier date, between 300 and 200 BCE. It is notable that Fitzmyer (2000:151) estimates the date of Tobit to be later between the end of 2 nd century BCE and the beginning of the 2 nd century CE, but notes that Albright claimed that Aramaic Tobit is older than Daniel. Daniel is dated to 167-163 BCE (Collins 1993:61); McLay (2015:546). 
for the one who gives alms. ${ }^{3}$ The question arises: if the Septuagint translators used the word $\dot{\varepsilon} \lambda \varepsilon \eta \mu \sigma v^{\prime} \alpha_{\varsigma}$ to describe almsgiving, why, and when, did the close association between mercy and righteousness become subsumed into צדק [righteousness without reference to mercy] as a synecdoche for almsgiving in Hebrew and Aramaic? How did this facile cart land up before the horse - instant righteousness and prosperity as reward if alms are given? Faced with the complexities of Semitic lexicography, no wonder Walter Bauer, in near despair, commented 'How great is the ocean, and how tiny the shell with which we dip!'4

\section{Methodology}

Let not mercy and truth forsake thee. Proverbs 3:3a (KJV)

The initial research question was whether there could be a direct semantic correlation of the Greek word $\dot{\varepsilon} \lambda \varepsilon \eta \mu$ rov́vas and רחם/חסד 'compassion/mercy' in the Semitic fragments of 4QTobit ${ }^{5}$ The first methodological step was thus to compare the expected association of these lexemes with the appearance of the lexeme צדק 'righteousness' in Semitic 4QTobit. The surprising result was that the Aramaic lexeme for רחם 'mercy' only appears three times in all the fragments of 4QTobit, and in each position. it is described as a quality possessed by God, and is not in association with righteousness. ${ }^{6}$ Therefore, the search for a correlation of mercy or compassion in relation to righteousness in the Semitic 4QTobit and LXX copies was relinquished. Instead, a preliminary comparison of the association of these two qualities, mercy and righteousness in GI and GII was made. In both Greek versions, the lexeme $\ddot{\varepsilon} \lambda \varepsilon_{0} \varsigma$ is rendered in English as 'almsgiving' and the lexeme $\delta i ́ \kappa \eta$ as 'righteous'. The initial methodological step was to compare the semantic implication of the combination of these two lexemes in GI and GII. During this process of comparison, it was confirmed that the motivation for almsgiving is portrayed differently in different versions of Tobit. Therefore, the next methodological step was to compare the motivation for almsgiving between the Greek, Hebrew and Aramaic versions.

\section{Righteousness in the LXX and Qumran versions of Tobit}

In the deuteronomistically oriented introduction in GI and GII, Tobit describes himself as having walked in the ways of

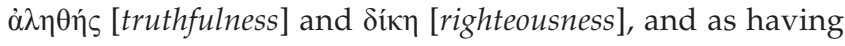
performed many acts of ह̌ $\lambda \varepsilon 0 \varsigma$ [charity] for his kin

3.The belief in the benefits of almsgiving as a means to obtain righteousness is firstly seen biblically in the Aramaic portion of the Book of Daniel 4:27 (Machiela 2017 personal communication). Anderson $(2011: 1,7)$ suggests that this 'striking new idea' - the 'ability to reduce or even eliminate one's culpability by accumulating "merits"' because sin was a debt that had to be repaid and was probably a result of the influence from Aramaic. Also see Zanella (2013)

4.Bauer, Arndt and Gingrich (1955:xxv). But see Gzella (2009:78) who states that 'linguistic dating of the Aramaic texts from Qumran is ripe for reinvestigation ... no existing chronology of the (Qumran Aramaic) texts should a priori be enforced on the study of the material'. He maintains that contextual features must be taken into account.

5.The Aramaic word רחרמין appears once in Dan at 2:18 (Holladay 1988:421).

6.In each case, it is God who shows mercy: 4Q197 4iii 1 (Tob 6:18); 4Q198 19 (Tob 14:5); 4Q200 66 (Tob 13:2).
(1:3). ${ }^{7}$ But then Tobit is accidentally blinded whilst performing his legalistic Jewish duties. A counterpoint to Tobit's claims to righteousness and honesty follows: Tobit, not being able to see accuses his wife Hanna of dishonesty. Provoked by his unjustified accusation she lashes out at him, challenging the truthfulness of his claim of $\check{\varepsilon} \lambda \varepsilon \eta \mu o \sigma u ́ v \alpha r$ and

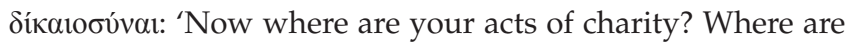
your righteous deeds? See, these things are known about you in the community!'8 After this rhetorical juxtaposition of righteousness and self-righteousness in which Hannah plants the suspicion in the reader's mind of the possibility that Tobit's claims to righteousness may be false, the griefstricken Tobit prays and acknowledges that it is God whose

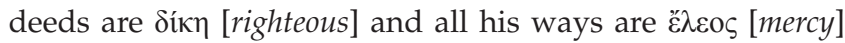
and $\dot{\alpha} \lambda \eta \theta \dot{s}$ [truth] (Tob 3:2). Although in his prayer, Tobit expresses the deuteronomistic orientation to theodicy that he is being punished for communal sins committed by his ancestors, ironically, he who falsely accused his wife complains that he has been falsely accused. ${ }^{9}$

When Tobit decides to send his son Tobiah on a perilous journey to retrieve his money deposited with a relative far away, Hannah provides another subversive hint. ${ }^{10}$ In her anxiety about the dangers of the journey, she pinpoints Tobit's materialistic drive for money at the cost of their son's safety: 'Do not add silver to silver' (GI and GII). This incident is also extant in 4Q197 Frg. 4i, line 1: 'Let my son not cling to money'. ${ }^{11}$ Again, a typical wisdom statement follows this subversive incident: as Tobiah departs on his journey, Tobit

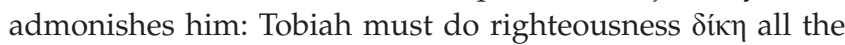
days of his life, and if he keeps to the truth $\dot{\alpha} \lambda \eta \theta \dot{\eta} s$, he will have success in all his deeds. Up to this point, GI and GII are virtually identical, but 12 additional verses in GI in which almsgiving is excessively emphasised introduce a crucial divergence which is not present in GII.

At GI 4:7ff., Tobit motivates his instruction to Tobiah to give alms $\ddot{\varepsilon} \lambda \varepsilon \sigma \varsigma$ with the promise of reward. That alms are to be given to all who do righteousness, but not to sinners is repeated several times. ${ }^{12}$ This striking proviso that the recipients of alms must also be righteous is strengthened as the passage continues in GI 4:9-11 with Tobit's instruction to his son: even if you have little, give alms $\tilde{c} \lambda \varepsilon \varsigma_{\zeta}$, because:

[Y]ou will be storing up a good treasure for yourself against the day of necessity. Therefore, alms delivers from death and prevents entering into darkness. For alms $\check{\varepsilon} \lambda \varepsilon_{0} \varsigma$ is a good gift to those who give them in the presence of the Most High. (vv. 9-11)

7.For the complexities of the term 'deuteronomistic', see Laato (2003:183-235). For instance, the centralisation of the Jerusalem Temple, the concept of 'the good land' and a sense of communal sin (Di Lella 1979:381, 385, 387). Also see Kiel (2011:268) for the shift in the Deuteronomistic theology in Tobit.

8.Tobit 2:13-14 in Gl and GII.

9.Tobit 3:6. The rhetorical device of irony reappears later in the narrative.

10.Tobit 4:5, 6a.

11.Tobit 5:19. See Macatangay $(2015: 76,83, n$. 26) on Tobit's concern over money as a denial of God's providence.

12.This entire passage Tobit $4: 7-18$ is not in GII, and not attested in any of the Aramaic copies from Qumran. 
This instance of self-centred motivation for almsgiving is not extant in any of the Aramaic versions, but is mirrored in the Hebrew copy 4Q200, fragment 2.

\section{Q200 Hebrew fragment 2 lines 6-9 Tobit 4:6-9 (Fitzmyer 1995:65)}

[] וכארך ידכה בני היה] עושה ]צדקות ואל תס[תר פניך מן כול]

[ע]נו אף ממכה לוא יס[תרו פני אלהי]ם 8אם יהיה לךה בנ]י רוב כרוב היה]

[עוסש] הממני צד [קו] ת[][אם יהיה לך מעט כמעט [ ]

בעש]ותך צדקה 9שימה טובה [ ]

6. [ ] According to your ability, my son, gi[ve] alms, [and hi[de] not [your face from any]

7. [ $p$ ]oor person. Then [Go]d['s face] will not be $\mathrm{h}[\mathrm{idden}]$ from you. 8 If you have [much, my] son, [according to (your) bounty]

8. [giv] e al $[\mathrm{m}] \mathrm{s}$ from it [vacat?] If you have little, according to the little (you have) [ ]

9. [By] your [giv]ing alms, 9 a good deposit [you]

The idea that almsgiving is 'a good deposit' is clearly stated in line 9. ${ }^{13}$ Stuckenbruck and Weeks (2015:255) warn that 'one should be cautious in assigning differences between the recensions to distinguishable ideologies', but the materialistic tone in 4Q200 is unmistakable in GI 4:9-10): 'For you will be storing up a good treasure for yourself against the day of necessity. Therefore almsgiving delivers from death and prevents entering into the darkness'. In contrast, GII breaks

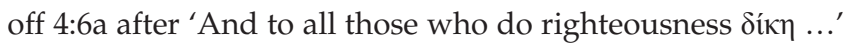
and continues at 4:19 with ' ... the Lord will give them good council'. There is no mention of almsgiving here in GII! ${ }^{14}$ This similarity between the Hebrew copy and GI suggests that there may well be a significant ideological difference between the only Hebrew copy 4Q200 and the four Aramaic copies 4Q196-199. ${ }^{15}$ For the contrast between the deuteronomistic history and other OT theologies, see Mayes (1997:57, 64), who notes that ideology has a legitimising function. Rose (2000:424) has warned that the term 'ideology' has very diverse connotations, and is sometimes used in a pejorative sense, but in this case, it is applied to try to find similarities and differences in motivation between the versions of the Book of Tobit. ${ }^{16}$ Interestingly, Weeks, Gathercombe and Stuckenbruck (2004:13) regard the 'missing' verses in GII as a result of carelessness on the part of the scribe, but this highly rhetorical passage in GI is the very one that stresses almsgiving and kinship to such an extent that a kind of 'prosperity cult' comes to mind. Therefore, I would like to

13.4Q200, Hebrew, Frg. 2 lines 6-9. Tobit 4:7-9a. c. 30 BCE to c. 20 CE (Fitzmyer 1995:65-66).

14.Cf. Proverbs 21:3 and Micah 6:8.

15.For the relation between GI and GII, see Di Lella (2007:456-456) and Stuckenbruck and Weeks (2015:238).

16.To make hard and fast judgements about ideological differences between the versions is always fraught with uncertainty because there is so much overlap that cannot be distinguished from recensions. suggest that the verses 4:7-18 in GI are more likely to be an addition, rather than missing in GII. ${ }^{17}$

The extra passage in GI Tobit 4:7-18 ends with the telling admonition to give alms $\varepsilon$ है $\varepsilon$ s to the naked and hungry who are righteous $\delta i ́ \kappa \eta$, but 'nothing to the sinners'. This conditional almsgiving is stated earlier in the passage, at 4:6b-7a. Support for the possibility of recension by an unwitting scribe is evident in the first appearance where a contradiction of logic arises: as if as an afterthought, the following comment is added to the directive to give alms to the righteous at $4: 7 \mathrm{~b}$ : 'to any poor person'. The anomalous addition 'to any poor' in GI 4:7 could be a correction for the instruction at GI 4:17: 'Spread out your bread on the grave of the righteous, but give nothing to the sinners'. The suspicion arises that the addition 'to any poor' is a premature recension or interpolation by an over-zealous, well-meaning scribe who lacked insight into Tobit's enlightenment which occurs after his blindness is healed. ${ }^{18}$ In both GII and GI, the turning point of the narrative actually only arises at 12:6-10 when Tobit's sight is restored and he asserts that mercy or almsgiving must be extended beyond the boundaries of his own kin. ${ }^{19}$

From chapter 4:19 onwards, the continuation of the narrative in both GI and GII is more or less identical until the last part of the narrative. However, as the narrative develops, another aspect of mercy other than almsgiving become dominant. At 6:18, Raphael (alias Azariah) instructs Tobiah to pray for God's mercy $\varepsilon \lambda_{\ell} \varepsilon \varsigma_{;}$in 7:11, Raguel repeats the instruction and in 8:4, Tobiah and Sara pray for God's mercy $\varepsilon \lambda \varepsilon \circ \varsigma$, and consequently, their problem is solved. It seems possible that the author intends to transfer the example of God's mercy to that of acts of mercy (in the form of almsgiving) by human race. In the last chapter in both GI and GII, the reader is told that after he was healed, Tobit made acts of almsgiving $\varepsilon$ $\lambda \varepsilon 0 \varsigma$ and increased in fear of the Lord, and praised him. In 4:11, another major difference between GI and GII occurs. In GI, Tobit tells Tobiah to 'see what almsgiving does and how righteousness delivers':

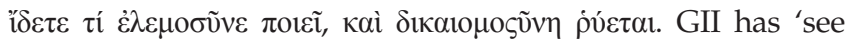
what almsgiving does, and what injustice does: it kills!': ' 'i $\delta \varepsilon \tau \varepsilon \tau i$

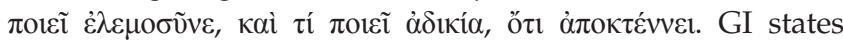
'righteousness delivers', whereas GII has 'injustice kills!'; thus, an equivalence between righteousness and justice is implied.

As the narrative draws to a close, in contrast to the incentive in GI 4:9 that if you give alms 'you will be storing up a good treasure for yourself against the day of necessity', in GII 12:89 , almsgiving with righteousness is stressed, rather than the short-circuiting in GI to the positive rewards of almsgiving as righteousness. ${ }^{20}$ The difference between LXX and MT in Proverbs 11:18b is an interesting example:

17.To my knowledge, these verses in Gl are not extant in any earlier witnesses.

18.Cf. Patmore (2007:241) who has suggested in the case of Ezekiel that the Qumran evidence has cast into doubt some of the currently accepted reconstructions of the Old Greek.

19.In another significant addition in GI 4:12-13 that is not in GII, loyalty and adherence to own kin is reinforced, again associated with reward: Tobit advises his son to take a wife from their own kindred as Abraham, Isaac and Jacob did: 'and their descendants will inherit the land'.

20.In both GI and GII at 12:10 in Tobit's prayer of rejoicing at the recovery of his sight, he instructs the 'sons of Israel' to acknowledge, bless and extol the Lord of 
וזרע צדקה שכר אמת 'but those who sow righteousness get a true reward'. (NRSV)

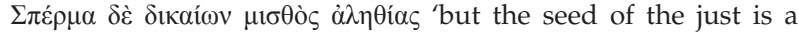
reward of truth'. (NETS)

In LXX, the just or righteous sow a certain seed, and truth is their reward; MT is more direct: 'those' sow the seed - the seed sown is 'righteousness', and 'those' who sow righteousness get a reward, unspecified, but which is true.

In GI $14: 10$ to $14: 13 \mathrm{~b}, 14 \mathrm{~b}$, the ending of the narrative reinforces the ethos of self-interested reward: Tobit tells Tobiah that Manassas (the evil one) gave alms $\varepsilon^{\prime} \lambda \varepsilon \varsigma_{\varsigma}$ and escaped death. The reader is told that Tobiah inherited the property of his parents-in-law, and rejoiced over the destruction of Nineveh. In striking contrast, in GII 14:8-10, the combination of righteousness, mercy or almsgiving and truth comes to the fore: Tobit tells his children that their

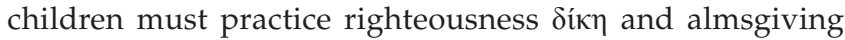
$\varepsilon \lambda^{\prime} \varepsilon \circ s$, and be mindful of God and with all their strength bless his name in truth $\dot{\alpha} \lambda \eta \theta \eta \dot{c}$. In GII the last word, as it were, is 'truth', in combination with 'and he blessed the Lord God for ever and ever' (14:14). This confirmation that GII is closer to 4Q196 and 4Q197 in ideological orientation led to the next methodological step: a semantic comparison of righteousness and truth between GI and the most complete and relevant Aramaic text (4Q196). ${ }^{21}$

\section{Comparison between $\mathrm{Gl}$ and 4QTobit Aramaic 4Q196, Fragment 10, line 1 Tobit 4:722}

[כארך [ידך ברי ע]בד צדקתא]

[according to what is in] your hand, my son, gi[ve alms]

In this fragment, Fitzmyer has reconstructed the phrase as if almsgiving is present. Yet, in the photograph of 4Q196 fragment 10, there is no evidence of צדקתא, and not even 'give' ${ }^{23}$ Fitzmyer must have decided to insert 'almsgiving' by referring to the Hebrew copy 4Q200, fragment 2 line 6 ('according to your ability my son, gi[ve] alms'), and to GI Tobit 4:7-4:19 which stresses almsgiving. ${ }^{24}$ The warning by Weeks et al. (2004:1, 5) against the self-reinforcing hazards of using later copies to reconstruct earlier manuscripts is

(footnote 20 continues.)

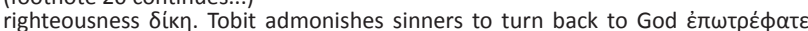
righteousness $\delta$ ikn. Tobit admonishes sinners to turn back to God $\varepsilon \pi \omega \tau \rho \varepsilon \phi \alpha \tau \varepsilon$ and then God will turn back to you' (13:6). Tobit tells Tobiah to consider what

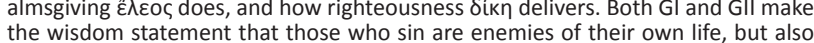
the wisdom statement that those who sin are enemies of their own life, but also
that 'Almsgiving $\ddot{\varepsilon} \lambda \varepsilon$ o delivers from death, and it purges away every sin'. Both that 'Almsgiving $\varepsilon$ है $\lambda \varepsilon \circ \varsigma$ delivers from death, and it purges away every sin'. Both of life, but $\mathrm{Gl}$ adds righteousness $\delta$ íkn here.

21.For dating, see Fitzmyer (1995:63) and Zanella (2013:271, diagram 2).

22.Fitzmyer 1995:17.

23.Plate III. Fitzmyer (1995:17). The presentation by Weeks et al. (2004:29, 141):

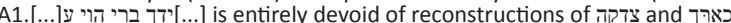

24.See Zanella (2013:269ff.) for an explanation of the Mishnaic concept of righteousness as a synecdoche for almsgiving. Zanella (2013:271, and n.7) notes that the syntagmic relationship between the lexemes צ צ and ' 7 in BH frequently occur in fixed pairs which actually lexicalize 'gift-giving', but not in Aramaic. pertinent, yet Weeks et al. (2004:13) regard the 'omitted' verses 4:7-18 as a result of carelessness on the part of the scribe, but no indication of almsgiving or of a materialistic tone is present in any of the Aramaic fragments.

Another indication of possible subversive rhetoric is to be seen in the Aramaic text 4Q197 4i, line 1 (Tob 5:19) where Edna again hints at false righteousness with regard to a materialistic orientation: 'Let my son not cling to [mon] ey, but (let it be for him) like [ ]'. Another possible hint of a deliberate rhetorical critique of a superficial claim to righteousness is to be seen in the same Aramaic text 4Q197 Frg. 4iii line 9 (Tob 7:7). Raguel expresses his approval of his kinsman Tobit when he exclaims to Tobiah 'you are the] so[ $n$ of $]$ a righteo[ $u s] \mathrm{man}^{\prime}{ }^{25}$ By alluding to his kinsman as righteous, Raguel implies that he himself is a righteous man (the reader knows better): A sardonic twist later emerges in both GI and GII. Raguel, in expectation that Tobiah will die, has secretly prepared a grave for him, and then - when to his surprise - Tobiah has survived, the reader is told at Tobit 8:18 that the apparently righteous Raguel quickly has the grave closed up so that no one will know what his expectations were. This wry touch of humour reinforces the subversive rhetoric about false righteousness, and it strengthens the suspicion that a subtly subversive rhetoric is undermining the stress on righteousness as reward for almsgiving, including material prosperity.

Towards the end of the narrative in all the versions under discussion, there is a striking shift away from materialism, or self-interest: Tobit's demeanour has changed. As if to emphasise the change, the word קושטא [truth] appears four times in the penultimate fragment of 4Q196.

\section{Q196, Fragment 17ii, lines 1-5 Tob 13:6 $6^{26}$}

לבכון ו[בכל נ]פוכון ל[מעבד קשטא אדין י]תפנה עליכון

ולא [יסתר אנפו]הי מנכון ע[וד והודו ]לה בכל פמכון

ובר]כו למרה ]קושטא ור] [וממו לה אנה בארעת] שביא מהודה לה

ומח[וה אנה לנ]בורתה ורבו[תה קדם עם חט]אין על לבבכון

קושטא עטדו ]קדמוה]י מן] יד[ע הן תהוה ס[ליחא[ לכון 7ולאלהי]

1. Your heart and [with all] your [s]oul to [do what is righteous. Then he] will turn you

2. And will no lon[ger hide hi]s [face] from you. [Now acknowledge] him with all your mouth,

3. And bl[ess the Lord of] righteousness, and ed[alt him. In the land of] captivity [I acknowledge him,

4. And [I] make kn[own] his [po]wer and [his] maj[esty before a sin]ful [people]. According to your heart

5. [do what is] right [eous] before hi[ $m$. Who] know [s whether $p]$ ardon[will be yours. 7I exalt my]

25.In the Aramaic, the adjective wo pendered here as 'righteous' is defined by Cook

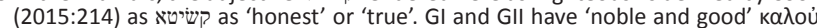

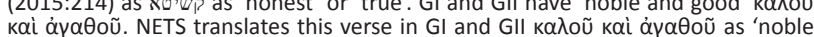
and good'. Compare Prov 22:21 where both words appear in the same sentence. KJV translates קושט as 'certainty'.

26.Fitzmyer 1995:26-27. 
In every instance where the lexeme קושטא appears (in lines 1, 3, 5 and 9), Fitzmyer renders it as righteousness or righteous. Vogt (2011:299) gives the meaning of קושטא as 'truth' or 'justice', as, for example, in the contemporaneous text Daniel 4:34. Because up to this point, he has translated the lexeme צדק as almsgiving, Fitzmyer's translation here of קושטא as almsgiving reinforces his stress on almsgiving. ${ }^{27}$ Compare the rendering of the passage by Garcia Martinez (1994), where קושטא is translated sequentially as 'truthfully or justice or justly' 28 :

... your heart and with all your soul to act truthfully before him. Then, he will turn to you and no longer hide his face from you. And now, consider what he has done for you and give him thanks with your whole mouth, and bless the Lord of justice, and exalt the eternal king. I, in the land of exile, give you thanks and declare his power and his greatness to a nation of sinners. Turn, you sinners, and with all your heart act justly before him. (n.p., [author's own italics])

According to this more straightforward translation by Garcia Martinez, here in the Aramaic fragment, the stress is on truth and justice, as it is in GII at Tobit 13:6.. ${ }^{29}$ If GI is indeed primarily about the benefits of almsgiving, then GII is certainly closer to the Aramaic version 4Q196. Interestingly, GII does not contain the tell-tale verses 13:7-9 in GI which are reminiscent of Daniel 4:27, and which refer confusingly and out of context to Jerusalem. ${ }^{30}$

\section{Q196 fragment 18, lines 14-15 Tobit 14:2 $\mathrm{b}^{31}$}

[חזות ע]ינוהי חי בטב ובכ[ל עבד]

[לברכה ל] ולהודיה רב[ותה 3 קרא]

14. [the sight of ] his [e]yes. He lived in goodness and in al[ $l$ he gave alms]

15. [to bless] the Lord and to acknowledge [his] majest[y. 3 he summoned]

Here, in 4Q196 Aramaic, the lexeme which Fitzmyer presents as 'alms' is not actually present, it is inserted. If almsgiving is indeed the subject of the largely reconstructed line 14, the true motivation for almsgiving is clearly not for personal reward, but to 'bless the Lord and acknowledge his majesty' ${ }^{32}$

\section{Discussion}

Simkovich (2014:1-2) has noted that the Book of Tobit was preserved at different times for different reasons. Just as the promotion of tithing would have appealed to Jews during Second Temple times, and to the early church, so charity

27.The lexeme קTצ does not appear at all, and Fitzmyer does not explain the reason for his choice to render קושטא as righteous.

28. From lines $5 b$ to the end of the fragment, the words are extremely fragmentary, Garcia Martinez does not reconstruct and translate them at all.

29.Garcia Martinez (1994:296) does not attempt to translate the very fragmentary lines 6-9 in Fragment 17ii.

30.GI Tobit 13:6b: 'Turn back, you sinners, and do what is just before him; who knows if he will take delight in you and grant mercy to you?'. These words are an almost exact repetition of the meaning of Daniel's words to King Nebuchadnezzar in Daniel 4:27.

31.Fitzmyer 1995:29-30

32.The phrase is present in both $\mathrm{GI}$ and GII. or almsgiving would have appealed to Jews experiencing poverty and an uncertain future during the medieval diaspora. The comparison of the Aramaic fragments from Qumran with the Septuagint versions suggests that possibly the first reconstructions and translations of 4QTobit may have been overly influenced by the many centuries of usefulness of the GI version.

Whereas the earliest Greek versions tend to emphasise almsgiving as a means to gain righteousness, the older Aramaic versions 4Q196 tends to highlight truthfulness as the primary value. In the case of the Hebrew version 4Q200, Fitzmyer's reconstruction and translation of צדק as almsgiving is justified, but in the Aramaic 4QTobit is questionable because in the Aramaic copies, the lexeme צד always appears in a reconstructed form. At least in 4Q196, the focus in the end appears to be more on truth as a quality of righteousness or justice than on almsgiving as righteousness. Even if in 4Q196 at Tobit 4:7 and Tobit 14:2b, the reconstruction (actually insertion) and translation of צדק as almsgiving is acceptable, the message of 4Q196 is still that truthfulness must be operative in almsgiving. Thus, ultimately, in Aramaic 4Q196, the motivation for giving alms would to bless and extol God, not for personal gain.

The deliberate subversive reflection of hypocritical righteousness perceptible in Tobit hints at cross currents. Dimant (2009:140 n. 88) has mentioned the possibility of concurrent contesting schools of halakah during Second Temple times for instance 'an older halakah, later changed and developed by the Tannaim' (cf. Nodet 2020:37). This would go some way to explain the different currents and subversive elements in the Book of Tobit, but as Dimant notes, the Qumran scrolls indicate that the situation was more complex. Part of the complexity of Tobit is the influence of Hellenism, for instance, the high value placed on Philanthropia in Greek culture. ${ }^{33}$ The shift from the Deuteronomistic kinship altruism orientation in the Book of Tobit reflects a response not only to the later prophets such as Jonah, Amos and Micah to observe charity to 'the nations' as a form of witnessing to God's majesty but also to the Hellenistic cultural context. ${ }^{34}$

The results of this enquiry raise more questions than answers. Could the concept of almsgiving as righteousness which is prominent in the Hebrew version 4Q200 and in GI be evidence of the oral phase of the Mishna? Does 4Q200 reflect a Hebrew vorlage which propounded the rhetoric of reward of righteousness and prosperity for kinship almsgiving during the deuteronomistic era of nation building? Could the GI version be a translation from the Hebrew 4Q200? Traditionally, Israelite biblical theology has ignored biblical

33.Simkovich (2014:3). Weeks (2016:8) has pointed out a deeper, more ominous aspect of the effect of wisdom literature on Deuteronomistic rhetoric: wisdom literature is affiliated with a broad international movement that is inclined towards
the idea that humans can save themselves, and that they can themselves establish a real relationship with God. Weeks sees this aspect of wisdom literature as a cuckoo in the biblical nest. The idea that giving alms is rewarded by righteousness cuckoo in the biblical nest. The idea that giving alms is rewarded by righteousness
in God's sight, and hence ultimate salvation, which is promoted in Gl and 4Q200 Hebrew, is a case in point.

34.Kiel (2012:269). For the contrast between Old Testament theology and the deuteronomistic history, see Mayes 1997:57. 
associations with foreign literature (Weeks 2016:8). Could the GII version have been influenced by the original Aramaic? If so, this would contradict Anderson's suggestion mentioned in n.3, because the 4Q196 fragments have no definite evidence of almsgiving, but portray an ideal of witnessing to all nations by blessing God with truthfulness in heart and soul.

\section{Conclusion}

In the end, in the final fragment of 4Q196 when Tobit is healed and his vision restored, he redefines the true way to achieve righteousness: the healed Tobit lived in goodness and in all [he gave alms] to bless the Lord and to acknowledge his majesty'. The penultimate fragment makes it clear that truth in combination with justice must be operative if the motivation is to bless, praise and extol God's majesty. I would like to suggest that the Book of Tobit was part of the transition away from the deuteronomistic rhetoric of national identity formation. The syncretistic tendency of Hellenism reinforced the message of the prophets of unconditional inclusion of all nations in the orbit of God's mercy, rather than caring for Jewish righteous kin only. The enduring fascination and relevance of the narrative of Tobit is that although it has a Torah setting, millennia before Darwin, it explores the implications of the deuteronomistic theodicy of $\sin$ and punishment. ${ }^{35}$

Earlier research argued that 4Q196Tobit is a subversive rhetorical construction aimed at exposing the lack of truthfulness in the 'shortcut' giving of alms to attain righteousness. This article suggests the possibility that the ending of the Aramaic copy 4Q196 indicates that it is not primarily about almsgiving at all. However, to make judgements of theological or ideological differences between the versions, it is necessary to have a better understanding of the halakhic cross currents in Second Temple theologies and their relation to the dating of Tobit. Greatly improved new technical resources for the study of ancient fragments are becoming increasingly available, and hold out the promise of new ways to confirm suspicions such as those raised in this article.

\section{Acknowledgements Competing interests}

The author declares that she has no financial or personal relationships that may have inappropriately influenced her in writing this article.

\section{Author's contributions}

A.H.M.E. is the sole author of this research article.

\section{Ethical considerations}

This article followed all ethical standards for research without direct contact with human or animal subjects.

35.It evinces an adjustment of legalism. In this respect, it can be seen as a forerunne of another mysterious text found at Qumran and Masada, $4 Q$ Songs of the Sabbath
Sacrifice, which propounds truthful, genuine compassion as a means to extol the Sacrifice, which
nature of God.

\section{Funding information}

This research received no specific grant from any funding agency in the public, commercial or not-for-profit sectors.

\section{Data availability}

Data sharing is not applicable to this article as no new data were created or analysed in this study.

\section{Disclaimer}

The views and opinions expressed in this article are those of the author and do not necessarily reflect the official policy or position of any affiliated agency of the author.

\section{References}

Amit, Y., 2000, Hidden Polemics in Biblical narrative, transl. from Hebrew by J. Chipman, Brill, Leiden.

Anderson, G.A., 2011, 'How does almsgiving purge sins?', in S.E. Fassberg, M. Bar Asher \& R.A. Clements (eds.), Hebrew in the Second Temple period: The Hebrew of the Dead Sea Scrolls and of other contemporary sources, pp. 1-15, Brill, Leiden.

Bauer, W., Arndt, W.F. \& Gingrich, F.W., 1955, A Greek-English Lexicon of the New Testament and other Early Christian literature, Cambridge University Press, Cambridge.

Collins, J.J., 1993, Daniel. A Commentary on the Book of Daniel, Hermeneia, Fortress Press, Minneapolis, MN.

Cook, E.M., 2015, Dictionary of Qumran Aramaic, Eisenbrauns, Winona Lake, IN.

Di Lella, A.A., 1979, 'The Deuteronomic background of the farewell discourse in Tob $14: 3-11^{\prime}$, CBQ 41(v), 380-389.

Di Lella, A.A., 2007, 'Tobit', in A. Pietersma \& B.G. Wright (eds.), New English Translation of the Septuagint, pp. 456-477, Oxford University Press, New York, NY.

Dimant, D., 2009, 'The book of Tobit and the Qumran Halakah', in D. Dimant \& R. Kantz (eds.), The dynamics of language and exegesis at Qumran, Forschengen zum Alten Testament, pp. 121-142, 2 Reihe 35, Mohr Siebeck, Tubingen.

Fitzmyer SJ, J.A., 1995, 'Tobit', in M. Broshi et al. (ed.), Discoveries in the Judaean Desert XIX. Qumran Cave 4 XIV, pp. 1-76, Clarendon Press, Oxford.

Fitzmyer SJ, J.A., 2000, The Dead Sea Scrolls and Christian origins, Eerdmans, Grand Rapids, MI.

Garcia Martinez, F., 1994, The Dead Sea Scrolls translated. The Qumran texts in English, Brill, Leiden.

Gzella, H., 2009, 'Dating the Aramaic texts from Qumran: Possibilities and limits', Revue de Qumran 24(1), 61-67.

Holladay, W.L., 1988, A Concise Hebrew and Aramaic Lexicon of the Old Testament, Brill, Leiden.

Kiel, M.D., 2012, The whole truth: Rethinking retribution in the book of Tobit, Library of Second Temple Studies 82, T \& T Clark, London.

Kohler, K, 1906, Alms, 1295-alms, viewed 09 April 2018, from www.jewishencyclopedia. com/articles.

Laato, A., 2003, 'Theodicy in the Deuteronomistic history', in A. Laato \& J.C. De Moor (eds.), Theodicy in the World of the Bible, pp. 183-235, Brill, Leiden.

Macatangay, F.M., 2015, 'Metaphors and the character construction of Tobias in the Book of Tobit', in M. Witte \& Sven Behnke (eds.), The metaphorical use of language in deuterocanonical and cognate literature, pp. 75-86, De Gruyter, Berlin.

Machiela, D., 2017, Personal communication.

Mayes, D.H., 1979, Deuteronomy, NCBC, Eerdmans, Grand Rapids.

McLay, R.T., 2015, 'Daniel (Old Greek and Theodotion)', in J. Aitken. (ed.), T\&T Clark companion to the Septuagint, pp. 544-554, T\&T Clark, Bloomsbury.

Nodet, E., 2020, 'Halakha in the 3nd temple period?', in U. Gabbay \& J.-J. Peren-nes (eds.), Des polytheisms aux monotheismes: Melanges d'assyrio-logie offerts a Marcel Sigrist, pp. 37-50, Peeters, Leuven.

Patmore, H.M., 2007, 'The shorter and longer texts of Ezekiel: The implications of the manuscript finds from Masada and Qumran', JSOT 32/2(v), 231-242.

Rose, M., 2000, 'Deutshe ideology and theology of the Old Testament', in A. De Pury, T. Rowers \& J.-P. Macchi (eds.), Israel constructs its history. Deuteronomistic historiography in recent research, pp. 424-456, Sheffield Academic Press, Sheffield.

Simkovich, M.Z., 2019, Sefer Tuviah - The Book of Tobit, viewed 20 October 2019, from https://www.thetorah.com/article/sefer-tuviah-the-book-of-tobit-anancient-jewish-novel-for shavuot 2019/10/20.

Stuckenbruck, L. \& Weeks, S., 2015, 'Tobit', in J. Aitken (ed.), T\&T Clark companion to the Septuagint, pp. 237-260, Bloomsbury Publishing Pic, London. 
Vogt, E., 2011, A lexicon of biblical Aramaic clarified by ancient documents, transl. and revised by J.A. Fitzmyer SJ, Gregorian and Biblical Press, Rome.

Weeks, S., 2016, 'Is "wisdom literature" a useful category?', in H. Najman, J.S. Rey \& E. S. Tigchelaar (eds.), Tracing Sapiential traditions in Ancient Judaism, Supplements to the Journal for the Study of Judaism 174, pp. 3-23, Brill, Leiden.
Weeks, S., Gathercombe, S. \& Stuckenbruck, L. (eds.), 2004, The book of Tobit. Texts from the Principal Ancient and Medieval traditions, Walter de Gruyter, Berlin.

Zanella, F., 2013, "Between "righteousness" and "alms"; A semantic study of the lexeme צדקה in the Dead Sea Scrolls', in S. Fassberg, M. Bar-Asher \& R. Clements (eds.), Hebrew in the second temple period. The Hebrew of the Dead Sea scrolls and of other contemporary sources, pp. 269-287, Brill, Leiden. 